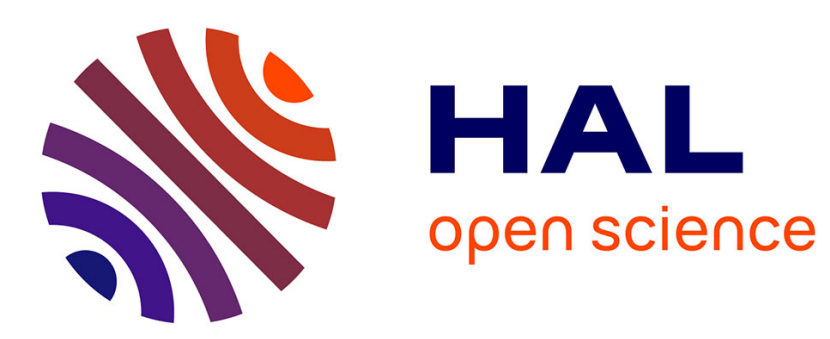

\title{
Charcoal consumption and casting activity by Pontoscolex corethrurus (Glossoscolecidae)
}

Stéphanie Topoliantz, Jean-François Ponge

\section{To cite this version:}

Stéphanie Topoliantz, Jean-François Ponge. Charcoal consumption and casting activity by Pontoscolex corethrurus (Glossoscolecidae). Applied Soil Ecology, 2005, 28 (3), pp.217-224. 10.1016/j.apsoil.2004.08.003 . hal-00497050

\section{HAL Id: hal-00497050 https://hal.science/hal-00497050}

Submitted on 2 Jul 2010

HAL is a multi-disciplinary open access archive for the deposit and dissemination of scientific research documents, whether they are published or not. The documents may come from teaching and research institutions in France or abroad, or from public or private research centers.
L'archive ouverte pluridisciplinaire HAL, est destinée au dépôt et à la diffusion de documents scientifiques de niveau recherche, publiés ou non, émanant des établissements d'enseignement et de recherche français ou étrangers, des laboratoires publics ou privés. 
1 Type of contribution: Original research paper

2

3 Title: Charcoal consumption and casting activity by Pontoscolex corethrurus (Glossoscolecidae)

4

5 Names of authors: Stéphanie Topoliantz, Jean-François Ponge

6

7 Address: Museum National d'Histoire Naturelle, CNRS-UMR 5176, 4 avenue du Petit-Château,

891800 Brunoy, France

9

10 Corresponding author: Jean-François Ponge, tel. $+33-1-60479213$, fax $+33-1-60465009$, E-mail

11 address: jean-francois.ponge@wanadoo.fr

12 
Abstract

The endogeic earthworm Pontoscolex corethrurus (Glossoscolecidae) is a peregrine species commonly found in tropical lands cleared by man for cultivation. We compared the charcoal consumption and casting activity of a population of $P$. corethrurus from a cultivated area under repeated slash-and-burn (fallow population) with that of a population living in a field cultivated after recent burning of a mature forest (forest population). Their cast production was measured in containers in the presence of pure charcoal, soil of fallow and forest origin, or a mixture of charcoal and soil. The forest population defecated less in pure charcoal than in forest soil, whereas the reverse was observed in the fallow population. When living in fallow soil, both populations defecated more at the surface of a mixture of charcoal and soil than at the surface of pure soil ( $x 2$ and $\times 3$ with fallow and forest population, respectively). In forest soil, both populations showed an increased charcoal consumption $(x$ 12). In the light of these experiments, we hypothesized that an adaptation of $P$. corethrurus to charcoal and fallow soil exists, supporting the observed distribution of this earthworm species in tropical open lands.

Key-words: Slash-and-burn; Forest; Fallow; Tropical earthworms; Population origin; Soil ingestion

\section{Introduction}

Slash-and-burn cultivation, currently practised in tropical rain forests, transforms the pre-burn biomass into fertile ashes and charcoal (Fearnside et al., 1999; Graça et al., 1999). Under heavy rain, fertile ashes are rapidly lost through leaching and surface runoff whereas charcoal remains in the soil for centuries, constituting with charred plant material an important sink of carbon and a source of persistent soil organic matter in burnt soils (Seiler and Crutzen, 1980; Glaser et al., 2001). Charcoal is also an efficient adsorbent of soluble organic and mineral compounds leached from litter and can support microbial communities, due to its high internal surface area made of interconnected micropores (Pietikäinen et al., 2000). Through its sorptive properties, charcoal enhances the degradation of litter phenolic compounds which may biochemically interfere with plant germination, 
1 thus playing a fundamental role in forest regeneration. This has been especially demonstrated in

2 boreal forests (Zackrisson et al., 1996; Wardle et al., 1998).

In tropical earthworm communities, post-burn environmental changes lead to the disappearance of specific forest species and the establishment of peregrine species commonly found in open land like the geophagous earthworm Pontoscolex corethrurus (Standen, 1988; Römbke and Verhaag, 1992). This earthworm species is highly adapted to tropical cultivated soils through its capacity to live and reproduce over a wide range of soil moisture and acidity conditions and its consumption of low-quality organic matter (Lavelle et al., 1987). Although many experiments have been conducted to study the cast production of $P$. corethrurus (Barois et al., 1993; Hallaire et al., 2000), no published paper mentions the casting activity of this earthworm species in the presence of charcoal. In a previous paper (Topoliantz and Ponge, 2003), we observed that $P$. corethrurus ingested charcoal and then incorporated it into the soil through defecation. Black and grey aggregates, originating from earthworm casts partly or totally made of powdered charcoal, were found in tropical soils under shifting cultivation (Topoliantz, 2002).

The aim of our study was to quantitatively analyse the behaviour of $P$. corethrurus when allowed to eat and defecate on soil, charcoal or charcoal-enriched soil. Two populations were compared, one from a mature forest which had been recently burnt for cultivation (forest population) and the other from an area repeatedly cultivated under slash-and-burn with short fallow duration (fallow population). This allowed us to detect possible shifts in choice and casting behaviour of this peregrine species which could have developed in the course of time under repeated cultivation.

\section{Materials and methods}

\subsection{Experimental design}

The surface cast production and the growth rate of $P$. corethrurus were studied in plastic containers $(11 \times 8.5 \times 4 \mathrm{~cm})$ in the presence of soil and charcoal. Charcoal was prepared from charred wood taken from the surface of the fallow soil. The animals were collected from soil under shifting 
cultivation in French Guiana (South America). The first population, living in a field recently opened by burning a mature forest $\left(3^{\circ} 26^{\prime} 11^{\prime \prime} \mathrm{N} ; 53^{\circ} 59^{\prime} 01^{\prime \prime} \mathrm{W}\right)$, was called FOR (forest) population, and the other one, living in a 3-yr old fallow setting in a wide slash-and-burn cultivated area with short fallow duration and frequent burning, around the village of Maripasoula $\left(3^{\circ} 39^{\prime} 17^{\prime \prime} \mathrm{N} ; 54^{\circ} 02^{\prime} 21^{\prime \prime} \mathrm{W}\right)$, was called FAL (fallow) population. FOR and FAL soils did not differ to a great extent. Both were Oxisols, acidic $(\mathrm{pH}<$ $5)$ and sandy $(60-65 \%$ sand). The size of the experimental boxes was considered suitable for this small endogeic species, on the basis of previous observation (Topoliantz, 2002).

In the first experiment, the surface casting activity of both earthworm populations was studied in polystyrene containers, in which one half of each was filled with powdered charcoal and the other with soil of FOR or FAL origin. The FOR soil was collected in mature forest (more than 50-yrs old) in the immediate vicinity $(<50 \mathrm{~m})$ of the recently burnt field where the FOR population was sampled, and the FAL soil at the same location as the FAL earthworm population. Both soils were taken from the top first $20 \mathrm{~cm}$. Soils and charcoal were dried in open air immediately after collection then they were kept and transported to the laboratory in polythene bags. Once at the laboratory charcoal was ground in a ball mill then soils and powdered charcoal and soil were sieved at $2 \mathrm{~mm}$. Grinding of charcoal and sieving of soil and charcoal were judged necessary to fill our containers with homogeneous substrates. A piece of cardboard was inserted at the middle part of each container. The two compartments thus delineated were filled to $1 \mathrm{~cm}$ from the top with sifted soil or charcoal. The cardboard was removed, then both compartments were progressively moistened by spraying deionized water until all the substrate was uniformly moist. These conditions were maintained throughout the experiment, by weighing containers and adding water when necessary. For both populations and both soils, one subadult $P$. corethrurus was weighed then gently positioned by hand at the top middle part of each container (5 replicates for each combination). Containers were then kept covered throughout the experiment. Before the experiment worms of each population were kept alive in their original soil, without any additional food. In the second experiment, containers were filled on one side with FAL soil and on the other side with a 3:2 (w:w) mixture of charcoal and FAL soil 28 (CHAR+soil), then one subadult $P$. corethrurus was introduced (6 replicates for each population). 29 Table 1 shows some chemical features of the soil and charcoal substrates used for the experiments, 
after sieving and homogenizing. In both experiments, containers were maintained at $25^{\circ} \mathrm{C}$ in an 2 forced-air chamber for 20 days.

Casts produced at the soil or charcoal surface were removed daily for 20 days and sorted according to colour: brown (colour of the original soil), brown-grey (with a low content of charcoal), dark grey (with a medium content of charcoal) and black (with a high content of charcoal). Casts were oven-dried for $24 \mathrm{~h}$ at $105^{\circ} \mathrm{C}$, then weighed. At the end of each experiment all worms were weighed individually. All worms were found alive at the end of each experiment.

2.2. Statistical analyses:

In experiment 1 , the influence of earthworm population and soil origin (FAL or FOR) on total surface cast production and colour was analysed by two-way ANOVA. The influence of substrate (soil or charcoal) on surface cast production (total and sorted by colour) was tested separately for each earthworm population by two-way ANOVA. When necessary, data were log-transformed before ANOVA. When residuals did not follow a normal distribution after log-transformation, groups were compared by Kruskall-Wallis rank test (Sokal and Rohlf, 1995).

In experiment 2, the effects of population (FAL or FOR) and substrate (soil or CHAR+soil) on total cast production were analysed by two-way ANOVA. Means were compared by Tukey a posteriori tests. Casts produced on soil and CHAR+soil, sorted by colour, were compared for each population (6 replicates) by t-test or Mann-Whitney rank test when data were not normally distributed.

23

\section{Results}

3.1. First experiment: surface cast production in the presence of pure charcoal

All introduced earthworms survived and grew during the experiment. The mean individual fresh weight increased from $0.28 \pm 0.01 \mathrm{~g}$ at the the start to $0.45 \pm 0.02 \mathrm{~g}$ at the end of the experiment. The growth rate of $P$. corethrurus was not influenced either by population origin or by soil. Figure 1 
shows the mean cast production per day per earthworm. The highest and the lowest total surface cast production were obtained when the FAL population was reared in the FAL soil and the FOR soil, respectively. The FAL population produced 1.6 times more surface casts than the FOR population, when all substrates were combined (Table 2). Total surface cast production was twice more in FAL soil than in FOR soil, when the two earthworm populations were combined. Cast production was 3.6 times higher with FAL soil than with FOR soil at the surface of the soil substrate. No influence of population or soil origin was detected at the surface of charcoal.

8 6

Brown casts averaged $69.7 \pm 3.3 \%$ of the total surface cast production, while brown-grey casts, dark grey casts and black casts averaged $27.8 \pm 3.2 \%, 1.7 \pm 0.4 \%$ and $0.8 \pm 0.3 \%$ of the total surface cast production, respectively. When earthworm populations were combined, 4.5 times more brown casts were produced at the soil surface in the presence of FAL soil than of FOR soil (Table 3), and 12.3 times more dark grey casts were produced at the charcoal surface in the presence of FOR soil than of FAL soil. The FAL population produced 4.1 times more brown-grey casts at the charcoal surface than the FOR population. Black cast production was not influenced by soil or population origin.

As shown in Figure 1, more total casts were produced at the soil surface than at the charcoal surface except by FAL earthworms when in the presence of FOR soil (ANOVA, interaction population $\mathrm{X}$ soil, $\mathrm{F}=4.56, \mathrm{P}<0.05)$. However, when casts were sorted by colour, black and dark grey cast production did not differ between soil and charcoal. In the presence of FAL soil, the FAL population produced more brown casts $(\mathrm{t}=-3.82, \mathrm{P}<0.01)$ and the FOR population more brown-grey casts $(\mathrm{t}=$ $3.02, \mathrm{P}<0.05)$ at the soil surface than at the charcoal surface.

3.2. Second experiment: cast production in the presence of a mixture of charcoal and FAL soil

Like in previous experiment, all individuals survived and grew, irrespective of population origin and soil. The mean individual fresh weight increased from $0.42 \pm 0.03 \mathrm{~g}$ at the the start to $0.54 \pm 0.03 \mathrm{~g}$ at the end of the experiment. Figure 2 shows the mean cast production per day per earthworm. The

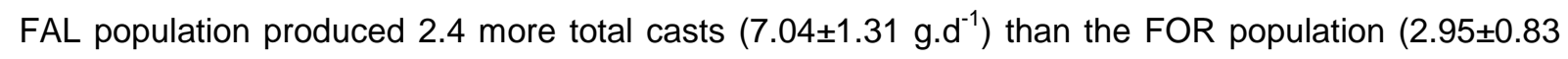
g. $d^{-1}$ ) when substrates were combined (Mann-Whitney, $T=53, P<0.05$ ). Cast production was 2.7 
times higher at the CHAR+soil surface $\left(7.28 \pm 1.33 \mathrm{~g} . \mathrm{d}^{-1}\right)$ than at the soil surface $\left(2.70 \pm 0.67 \mathrm{~g}^{-1} \mathrm{~d}^{-1}\right)$ when populations were combined $(T=55, P<0.01)$. Brown casts displayed the same significant trends as total casts, but black, dark grey and brown-grey cast production did not differ between both substrates and populations.

When substrates were combined, brown casts were the most abundant category $(87.0 \pm 3.7$ $\%)$, followed by brown-grey casts $(10.3 \pm 3.4 \%)$, dark grey casts $(1.7 \pm 1.0 \%)$ and black casts $(0.9 \pm 0.4$ $\%$, mean \pm SEM), corresponding to a decreasing order of soil content.

\section{Discussion}

P. corethrurus ingested powdered pure charcoal but in small amounts compared with soil. Less than $1 \%$ (in weight) of total cast production was black (made of pure or near pure charcoal). The low amount of black casts produced can be explained by the low bulk density of charcoal $\left(0.60 \mathrm{~g} . \mathrm{cm}^{-3}\right)$ as compared to soil $\left(1.35 \mathrm{g.cm}{ }^{-3}\right)$ in our containers. Indeed, Buck et al. (2000) demonstrated that cast production increased with soil bulk density. In our experiments, when charcoal was mixed with soil, black casts had a higher density (Topoliantz, 2002), thus they were thought to contain more soil than in the presence of pure charcoal. Thus the low production of black casts could result from the low bulk density of charcoal, through which earthworms could force their way without ingesting the substrate (Topoliantz and Ponge, 2003). However, it should be noticed that other colour categories than brown casts were characterized by the presence of charcoal mixed with soil (Topoliantz, 2002). The production of dark grey and brown-grey casts exemplifies the mixing effect of $P$. corethrurus on topsoil components (Barois et al., 1993). This biological process may explain the building of 'Terra Preta' Amazonian soils, where charcoal has been demonstrated to be a source of stable carbon (Glaser et al., 2001). In field conditions, charcoal and partly charred plant material, which are let at the soil surface after burning the forest, are ingested by $P$. corethrurus, which is able to grind and mix them with the mineral soil, depositing dark casts at the soil surface like in our experiments (Topoliantz, 2002). 
The cast production of $P$. corethrurus was higher on a mixture of charcoal and soil than on the original fallow soil. Inasmuch as cast production can be taken as a measure of habitat suitability 3 (Topoliantz and Ponge, 2003), our results suggest that the mixture of charcoal and soil was 4 preferentially used as living substrate. Earthworms possess a high chemosensitivity to acidity 5 (Laverack, 1961; Magdoom and Ismail, 1986). Although P. corethrurus is known to live in a wide range 6 of soil acidity (Lavelle et al., 1987), by mixing soil $(\mathrm{pH} 4)$ with charcoal $(\mathrm{pH} 7)$ it may decrease the acidity of its immediate environment. This process can complement buffering properties of external mucus (Schrader, 1994).

The two studied populations consumed similar amounts of charcoal but their behaviour towards forest or fallow soil differed strongly between them. The fallow population produced more casts on charcoal in the presence of forest soil, while the casting activity of the forest population was higher on soil whatever the soil origin (fallow or forest). Although P. corethrurus is probably indigenous to the rain forest of the Guiana plateau (Righi, 1984), few reports have been made on its abundance in tropical forest soils. Martinez and Sanchez (2000) found that the earthworm population of an evergreen forest in Cuba was dominated by P. corethrurus, and Zou and Gonzalez (1997) observed the presence of this species at all stages of vegetation succession after abandonment of pastures in Puerto Rico. From our results, it appears that the forest population is suited to forest as well as to fallow soils, and thus is able to colonize habitats created by slash-and-burn agriculture. Such behaviour was not shown by the fallow population, which seemed to be more restricted in its requirements. We cannot discount the possibility that other factors than management could explain the observed differences between the forest and the fallow population, since they were geographically separated along the Maroni river (see Materials and methods). However, we must emphasise the fact that both populations were living in acid, sandy soils, the only difference being the richness of the forest soil in organic matter (Table 1).

Both populations produced more brown casts in the presence of the fallow soil compared with the forest soil, probably because of low nutrient quality of the former ( $34 \%$ less $\mathrm{C}, 36 \%$ less $\mathrm{N}$ ). It is known that turnover of the soil by earthworms increases when the quality of soil organic matter decreases (Flegel and Schrader, 2000). The fallow population produced more than twice the amount 
of casts produced by the forest population, without increasing its growth rate (Topoliantz, 2002). This difference in cast production can be considered as a compensatory mechanism, the higher ingestion rate of the fallow soil compensating for its low nutrient content.

4

23

It has been suggested that soil fertility and soil biological activity might decrease under repeated slash-and-burn cultivation with short fallow periods (Kleinman et al., 1995). By elsewhere, Pontoscolex corethrurus, which thrives after deforestation of neotropical rain forests (Römbke and Verhaag, 1992), is sometimes considered as a pest in Amazonian pastures, where coalescence of its surface casts forms a compact crust which prevents infiltration of water and penetration of roots (Chauvel et al., 1999). However, we demonstrated that in the presence of charcoal this species improved soil properties, by increasing $\mathrm{pH}$ and incorporating stable carbon to the mineral soil (Topoliantz, 2002; Topoliantz and Ponge, 2003). To the light of our results, we suspect that $P$. corethrurus was the chief agent of the formation of the fertile Terra Preta in Brazil (Glaser et al., 2001). Natural populations living in fallow soil have been used in bioremediation experiments using charcoal and manioc peels at Maripasoula (Topoliantz et al., 2002). The increased casting activity of the fallow (FAL) population of $P$. corethrurus in the presence of charcoal and soil may help to explain how this species, which is present at low densities in the mature forest, may benefit from repeated cultivation. We demonstrated that charcoal/soil mixture was more attractive than soil itself (Fig. 2). Thus, the incorporation of charcoal to the mineral soil, in the form of casts of varying charcoal content, from brown-grey to black (Topoliantz, 2002), may act as a positive feed-back on the earthworm population.

\section{Acknowledgements}

We thank the SOFT Program of the French Ministry for the Environment and the GISSILVOLAB of French Guiana for their financial supports and we are grateful to Jean-Pierre Rossi for his help in earthworm sampling in French Guiana.

\section{References}


Barois, I., Villemin, G., Lavelle, P., Toutain, F., 1993. Transformation of the soil structure through Pontoscolex corethrurus (Oligochaeta) intestinal tract. Geoderma 56, 57-66.

Buck, C., Langmaack, M., Schrader, S., 2000. Influence of mulch and soil compaction on earthworm casts properties. Appl. Soil Ecol. 14, 223-229.

Chauvel, A., Grimaldi, M., Barros, E., Blanchart, E., Desjardins, T., Sarrazin, M., Lavelle, P., 1999. Pasture damage by an Amazonian earthworm. Nature 398, 32-33.

Fearnside, P.M., Graça, P.M.L.D.A., Leal Filho, N., Rodrigues, F.J.A., Robinson, J.M., 1999. Tropical forest burning in Brazilian Amazonia: measurement of biomass loading, burning efficiency and

Flegel, M., Schrader, S., 2000. Importance of food quality on selected enzyme activities in earthworm

Glaser, B., Haumaier, L., Guggenberger, G., Zech, W., 2001. The 'Terra Preta' phenomenon: a model for sustainable agriculture in the humid tropics. Naturwissenschaften $88,37-41$.

Graça, P.M.L.A., Fearnside, P.M., Cerri, C.C., 1999. Burning of Amazonian forest in Ariquemes, Rondônia, Brazil: biomass, charcoal formation and burning efficiency. For. Ecol. Manag. 120, 179-191.

23

Hallaire, V., Curmi, P., Duboisset, A., Lavelle, P., Pashanasi, B., 2000. Soil structure changes induced by the tropical earthworm Pontoscolex corethrurus and organic inputs in a Peruvian ultisol.

Kleinman, P.J.A., Pimentel, D., Bryant, R.B., 1995. The ecological sustainability of slash-and-burn agriculture. Agr. Ecosyst. Environ. 52, 235-249. 
Lavelle, P., Barois, I., Cruz, I., Fragoso, C., Hernandez, A., Pineda, A., Rangel, P., 1987. Adaptive strategies of Pontoscolex corethrurus (Glossoscolecidae, Oligochaeta), a peregrine geophagous earthworm of the humid tropics. Biol. Fertil. Soils 5, 188-194.

4

Laverack, M.S., 1961. Tactile and chemical perception in earthworms. II- Responses to acid pH solutions. Comp. Biochem. Physiol. 2, 22-34.

Magdoom, K.M.M., Ismail, S.A., 1986. Studies on chemosensitivity of the megascolecid earthworm Lampito mauritii. Pedobiologia 29, 229-235.

Martinez, M.A., Sanchez, J.A., 2000. Comunidades de lombrices de tierra (Annelida: Oligochaeta) en un bosque siempre verde y un pastizal de Sierra del Rosario, Cuba. Caribbean J. Sci. 36, 94103.

14

Pietikäinen, J., Kiikkilä, O., Fritze, H., 2000. Charcoal as habitat for microbes and its effect on the microbial community of the underlying humus. Oikos $89,231-242$.

Righi, G., 1984. Pontoscolex (Oligochaeta, Glossoscolecidae) a new evaluation. Stud. Neotrop. Fauna

Römbke, J., Verhaag, M., 1992. About earthworm communities in a rain forest and an adjacent pasture in Peru. Amazoniana 12, 29-49.

23

Schrader, S., 1994. Influence of earthworms on the $\mathrm{pH}$ conditions of their environment by cutaneous mucus secretion. Zool. Anz. 233, 211-219.

26

Seiler, W., Crutzen, P.J., 1980. Estimates of gross and net fluxes of carbon between the biosphere and the atmosphere from biomass burning. Clim. Chang. 2, 207-247.

29

Sokal, R.R., Rohlf, F.J., 1995. Biometry. W.H. Freeman, New York, 887 pp. 
2 Standen, V., 1988. Oligochaetes in fire climax grassland and conifer plantations in Papua New Guinea. J. Trop. Ecol. 4, 39-48.

4

5 Topoliantz, 2002. Réponse fonctionnelle de la pédofaune à la mise en culture itinérante et permanente des sols du sud-ouest de la Guyane française. Doctorate thesis, Museum National d'Histoire Naturelle, Paris, 194 pp.

8

Topoliantz, S., Ponge, J.F., 2003. Burrowing activity of the geophagous earthworm Pontoscolex corethrurus (Oligochaeta: Glossoscolecidae) in the presence of charcoal. Appl. Soil Ecol. 23, 267-271.

12

Topoliantz, S., Ponge, J.F., Arrouays, D., Ballof, S., Lavelle, P., 2002. Effect of organic manure and the endogeic earthworm Pontoscolex corethrurus (Oligochaeta: Glossoscolecidae) on soil fertility and bean production. Biol. Fertil. Soils 36, 313-319.

16

Wardle, D.A., Zackrisson, O., Nilsson, M.C., 1998. The charcoal effect in boreal forests: mechanisms and ecological consequences. Oecologia 115, 419-426.

19

20

Zackrisson, O., Nilsson, M.C., Wardle, D.A., 1996. Key ecological function of charcoal from wildfire in the Boreal forest. Oikos 77, 10-19.

22

23 Zou, X., Gonzalez, G., 1997. Changes in earthworm density and community structure during secondary succession in abandoned tropical pastures. Soil Biol. Biochem. 29, 627-629. 


\section{Figure captions}

2

3 Fig. 1. Experiment 1. Mean daily cast production by Pontoscolex corethrurus from fallow and forest populations in the presence of fallow and forest soil and pure charcoal.

5

6 Fig. 2. Experiment 2. Mean daily cast production by Pontoscolex corethrurus from fallow and forest populations in the presence of fallow soil and a mixture of charcoal and fallow soil.

8 


\section{Table 1}

Chemical features ( $\mathrm{pH}$. total $\mathrm{C}$ and $\mathrm{N}$ content) of incubating substrates sieved at $2 \mathrm{~mm}$

\begin{tabular}{lcccc}
\hline Substrate & $\mathrm{pH}$ & $\mathrm{C}\left(\mathrm{g} \cdot \mathrm{kg}^{-1}\right)$ & $\mathrm{N}\left(\mathrm{g} \cdot \mathrm{kg}^{-1}\right)$ & $\mathrm{C}: \mathrm{N}$ ratio \\
\hline Fallow soil & 4.63 & 28.8 & 2.15 & 13.40 \\
Forest soil & 4.16 & 43.7 & 3.37 & 12.97 \\
Wood charcoal & 7.06 & 675 & 8.63 & 78.14 \\
1 & 5.90 & 395 & 2.99 & 132.07 \\
\hline
\end{tabular}


Table 2

Experiment 1. Effect of earthworm population, soil origin and population $\mathrm{x}$ soil interaction on surface cast production (g.day ${ }^{-1}$ Mean \pm S.E.M. is given for each group -5 replicates) and $F$ value of ANOVA is given for each factor.Significant differences among groups are mentioned by stars: ${ }^{*} \mathrm{P}<0.05,{ }^{* *} \mathrm{P}<0.01$; ${ }^{* * *} \mathrm{P}<0.001$. The origin of earthworm populations and soils is abbreviated as following: fallow (FAL), forest (FOR)

\begin{tabular}{|c|c|c|c|c|c|c|c|}
\hline \multirow{2}{*}{ Total cast production } & \multicolumn{3}{|c|}{ Earthworm population } & \multicolumn{3}{|l|}{ Soil } & \multirow{2}{*}{$\begin{array}{l}\text { Interaction Population } x \text { Soil } \\
\text { F value }\end{array}$} \\
\hline & FAL & FOR & $\mathrm{F}$ value & FAL & FOR & $\mathrm{F}$ value & \\
\hline On charcoal surface & $0.10 \pm 0.02$ & $0.06 \pm 0.02$ & 2.67 & $0.07 \pm 0.02$ & $0.10 \pm 0.02$ & 1.78 & 2.71 \\
\hline On soil surface & $0.23 \pm 0.06$ & $0.15 \pm 0.03$ & 2.92 & $0.30 \pm 0.05$ & $0.08 \pm 0.01$ & $23.28^{\star * *}$ & $4.56^{\star}$ \\
\hline On total surface & $0.33 \pm 0.04$ & $0.21 \pm 0.03$ & $5.23^{*}$ & $0.36 \pm 0.04$ & $0.18 \pm 0.02$ & $12.20^{\star \star}$ & 1.04 \\
\hline
\end{tabular}


Table 3

Experiment 1. Effects of earthworm population, soil origin and population $x$ soil interaction on surface production of brown, brown-grey and dark grey casts (mg.day-1.ind-1). Mean \pm S.E.M. is given for each group (5 replicates) and $F$ value of ANOVA is given for each factor.Significant differences among groups are mentioned by stars: ${ }^{*} \mathrm{P}<0.05,{ }^{\star *} \mathrm{P}<0.01$; ${ }^{\star * *} \mathrm{P}<0.001$. The origin of earthworm populations and soils is abbreviated as following: fallow (FAL), forest (FOR)

\begin{tabular}{|c|c|c|c|c|c|c|c|}
\hline \multirow{2}{*}{ Cast production } & \multicolumn{3}{|c|}{ Earthworm population } & \multicolumn{3}{|l|}{ Soil } & \multirow{2}{*}{$\begin{array}{l}\text { Interaction Population } \times \text { Soil } \\
\text { F value }\end{array}$} \\
\hline & FAL & FOR & $\mathrm{F}$ value & FAL & FOR & $\mathrm{F}$ value & \\
\hline \multicolumn{8}{|l|}{ Brown } \\
\hline On charcoal surface & $56.2 \pm 12.6$ & $48.8 \pm 16.9$ & 0.14 & $45.6 \pm 14.6$ & $59.4 \pm 14.9$ & 0.49 & 4.38 \\
\hline On soil surface & $183 \pm 57$ & $101 \pm 25$ & 3.61 & $232 \pm 49$ & $51.9 \pm 5.2$ & $17.5^{\star \star \star}$ & 4.32 \\
\hline \multicolumn{8}{|l|}{ Brown-grey } \\
\hline On charcoal surface & $43.7 \pm 10.1$ & $10.6 \pm 5.8$ & $8.10^{*}$ & $18.8 \pm 8.1$ & $35.5 \pm 10.7$ & 2.06 & 0 \\
\hline On soil surface & $42.7 \pm 15.6$ & $48.2 \pm 12.6$ & 0.08 & $63.4 \pm 16.1$ & $27.6 \pm 8.5$ & 3.46 & 0.11 \\
\hline \multicolumn{8}{|l|}{ Dark grey } \\
\hline On charcoal surface & $2.83 \pm 1.10$ & $1.20 \pm 0.60$ & 3.26 & $0.29 \pm 0.20$ & $3.74 \pm 1.01$ & $14.56^{\star \star}$ & 4.08 \\
\hline On soil surface & $1.78 \pm 0.53$ & $1.43 \pm 0.52$ & 0.2 & $1.96 \pm 0.53$ & $1.25 \pm 0.50$ & 0.88 & 0.6 \\
\hline
\end{tabular}




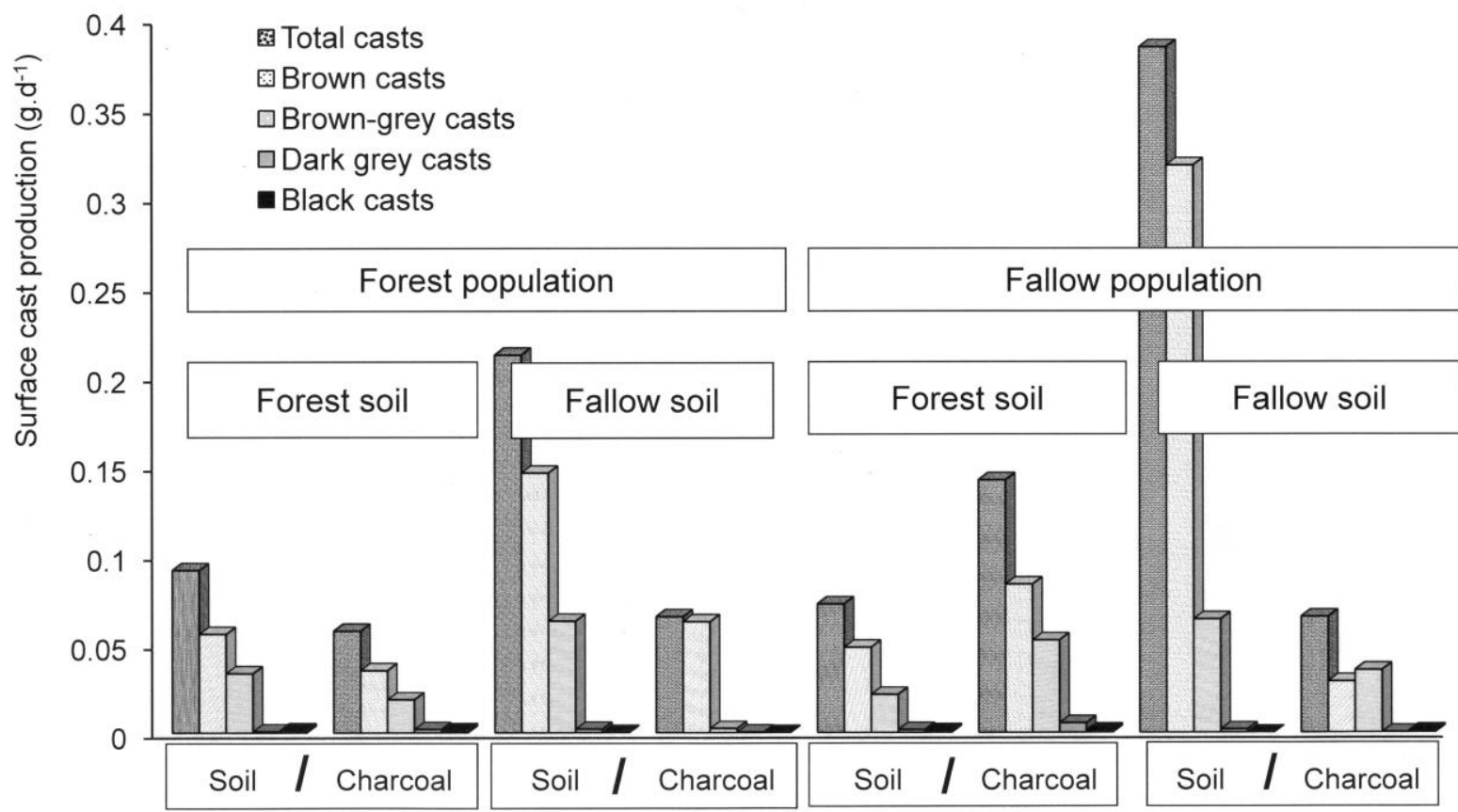

2 Fig. 1

3 


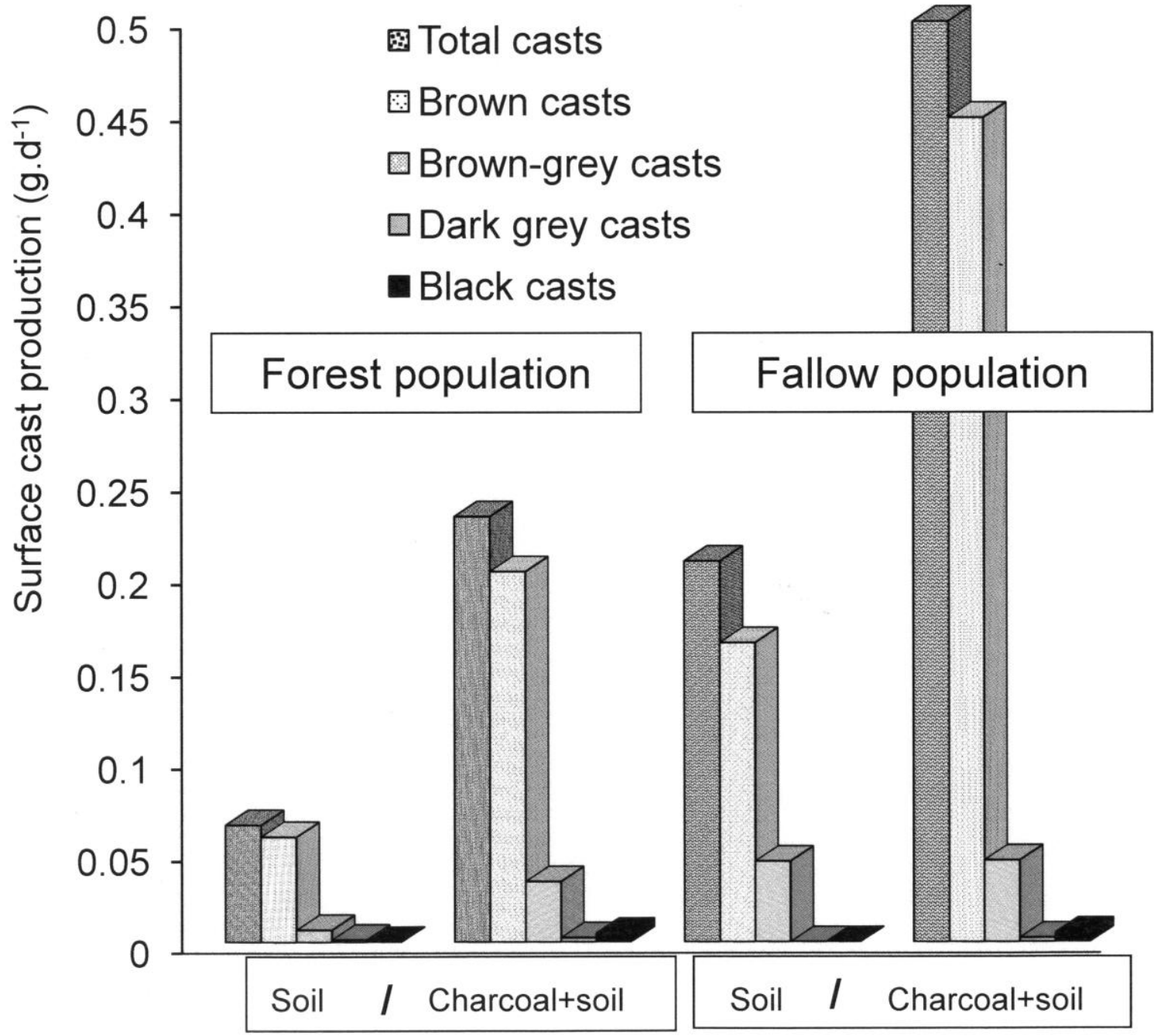

2 Fig. 2 